\title{
Role of weather on Alternaria Leaf Blight Disease and its effect on Yield and Yield Components of Mustard ${ }^{1}$
}

\author{
Sundar K Shrestha ${ }^{2}$, Lisa Munk ${ }^{3}$ and Suresh B Mathur ${ }^{4}$ \\ ${ }^{2}$ Plant Pathology Division-NARC, Khumaltar-Lalitpur-Nepal, < sundar_shrest84@ hotmail.com > \\ ${ }^{3}$ The Royal Veterinary and Agricultural University (KVL), Department of Plant Biology, Denmark \\ ${ }^{4}$ Danish Government Institute of Seed Pathology for Developing Countries, KVL, Denmark
}

\begin{abstract}
Alternaria leaf blight disease caused by Alternaria brassicae in mustard (Brassica juncea (L) Czern and Coss) was studied in two crop seasons, 1992 and 1993 in Nepal at Nawalpur, Sarlahi (Tarai) and Khumaltar, Lalitpur (mid hill). At Nawalpur, epidemics of the disease was recorded for both seasons. Weather conditions like humidity, temperature and frequent rainfall played key role for the epidemics. In experimental fields, the disease appeared first in mid-December when the relative humidity was more than $80 \%$ with maximum temperature ranging between $18-25^{\circ} \mathrm{C}$ and minimum between $10-14^{\circ} \mathrm{C}$. At Khumaltar, incidence of the disease was low in both seasons due to low average temperature from December to February. Among cultivars, Krishna and Pusabold were less susceptible than Varuna. Both mancozeb and iprodione had effectively reduced disease in the sprayed plots and increased seed yield by $48 \%$ and $130 \%$ respectively. The correlation between disease severity and yield, and yield components was negative and highly significant. Average yield loss was estimated to be in the range of 32 to $57 \%$. Seed infection was also significantly higher in non sprayed treatment than sprayed one. The disease showed a negative effect on oil content causing losses on oil between 4.2 to $4.5 \%$.
\end{abstract}

Key words: Alternaria brassicae, epidemics, iprodione, mancozeb, mustard, oil content

\section{INTRODUCTION}

Leaf blight caused by Alternaria brassicae (Berk.) Sacc. is an important disease of mustard (Brassica juncea (L.) Czern and Coss) and rapeseed (B. campestris L. var Toria) in the Indian sub-continent. In Nepal, our observations show that the disease occurs as a regular feature in the plains (Tarai and inner Tarai) causing heavy damage to the crops but in the midhill, the disease incidence is low. Severe infection causes substantial yield loss as a result of early defoliation, flower-bud abortion, premature ripening, siliquae dehiscence and seed shriveling (Seidle et al 1995). Yield losses of 20 to 30\% were recorded in Canada (McDonald 1959, Conn et al 1990). In India, losses of 15 to $71 \%$ were reported (Kadian and Saharan 1983; Singh and Bhowmik 1985, Kumar 1986, Ram and Chauhan 1998). Kolte et al (1987) reported the losses in 1000-seed weight of yellow sarson and mustard of $23 \%$ and $24 \%$ respectively. No factual data on yield loss due to the disease on rapeseed or mustard is available in Nepal. However, losses in yield of both rapeseed and mustard due to A. brassicae have been arbitrarily estimated between 20 and $50 \%$ from Chitwan (Tarai) district of the country (ATSP, USAID/HMG-NARC 1993) but the data on effect of the disease on different yield components are not available. The disease reduces the oil content of mustard. In Canada, losses in oil content up to $4.8 \%$ have been reported (Degenhardt et al 1974) but higher losses (14.6-36 \%) were recorded in India (Ansari et al 1988).

\footnotetext{
${ }^{1}$ The paper is based on $\mathrm{PhD}$ Thesis of the first author submitted to Royal Veterinary and Agricultural University (KVL), Copenhagen, Denmark.
} 
The effect of environmental factors, temperature $\left(15-25^{\circ} \mathrm{C}\right)$, relative humidity $(>80 \%)$ and leaf wetness (rain or dew) for 4-24 h, for the disease development and its epidemics have been reported from some countries like Canada (Degenhardt et al 1982), United Kingdom (Humpherson-Jones and Phelps 1989, Mridha and Wheeler 1993, Hong and Fitt 1995) and India (Ansari et al 1989). No such information is available in Nepal. The present investigation was therefore, undertaken to study the effect of environmental factors on Alternaria leaf blight and its effect on seed yield, yield components and oil content of mustard cultivars commonly grown in Nepal.

\section{MATERIALS AND METHODS}

Field experiments were conducted during two growing seasons, 1992 and 1993 at two locations, one in the mid hill (Khumaltar, Lalitpur, $27^{\circ} 42^{\prime} \mathrm{N}$ and $85^{\circ} 20^{\prime}$ E) and the other in the plain (National Oil Research Program (NORP), Nawalpur, Sarlahi, $27^{\circ} 48^{\prime} \mathrm{N}$ and $85^{\circ} 57^{\prime}$ E). These two different geographical regions were chosen because of their different climatic conditions. Besides, in these regions many different brassicaceous crops including mustard are grown intensively. Three commonly grown mustard cultivars, Pusabold, Varuna and Krishna were used in the experiments. In the first year, seeds received from National Bureau of Plant Genetic Resources (IBPGR), India were used, as the seed lot was found free from infection of Alternaria species. In the subsequent year, seeds of treated plots from Khumaltar were used. Prior to sowing, the seeds were tested by blotter method (Limonard 1966) and found free from infection of Alternaria species. A susceptible yellow sarson cultivar, Psy-6 (B. campestris var. sarson) was used for border planting in which, seed-infection level of A. brassicae was 8-10\%.

The experiments were carried out in factorial Randomized Complete Block Design (RCBD) with 6 replications. The factorial combination was $2 \times 3$ (treatments $\times$ cultivars). Each cultivar had two plots in each replication, one was fungicide-treated and the other untreated. Each plot was $3.75 \mathrm{x} 4 \mathrm{~m}$ with 10 rows, $40 \mathrm{~cm}$ space between rows, $60 \mathrm{~cm}$ distance from plot to plot and $75 \mathrm{~cm}$ between replications. The whole experimental block was surrounded by a single border row of yellow sarson at a distance of $60 \mathrm{~cm}$. At both locations and years, seeds were sown at $6 \mathrm{~kg} / \mathrm{ha}$ in the last week of October. Chemical fertilizers (NPK) were applied as per recommendation 60:40:40 kg/ha (NARC 1988). After 2-3 weeks of emergence, seedlings were thinned to 25 per row, each at a distance of $15 \mathrm{~cm}$. Weeding, irrigation and other cultural practices were done during the cropping period.

Two fungicides were applied: Dithane M-45 (mancozeb) @ $1.2 \mathrm{~kg} / \mathrm{ha}$ ai in 1992 and Rovral 50 WP (iprodione) $0.6 \mathrm{~kg} / \mathrm{ha}$ ai in 1993. A hand compression sprayer 'Marut' of 91 capacity (American Spring \&

Pressing Works Ltd, Mumbai, India) was used for spraying. The first spraying was done in the $2^{\text {nd }}$ week of December when the disease first appeared in the experimental plots. Subsequent sprays were done at an interval of 10-12 days. Total number of sprayings was 5 at Nawalpur and 2 at Khumaltar. At both locations, each plot, except the controls, received about 600-700 1/ha of fungicide solution each time. The control plots were sprayed with plain water. The disease was assessed once a week from the date of first appearance in the leaves and the assessments continued until total defoliation in the untreated plots. Pod infection was scored at 15 days intervals up to mid February. Disease scoring in the leaves and pods was done in 25 randomly tagged plants in each plot using a $0-5$ scale $(0=$ no infection, $1=1-5 \%$ area covered by the disease, $2=6-10 \%$ area covered, $3=11-20 \%$ area covered, $4=21-30 \%$ area covered, $5=$ $31-100 \%$ area covered). A set of pictorial disease scale $0-5$ in the leaves and pods are also shown in Figure $1 \mathrm{~A}$ and $\mathrm{B}$.

The percentage of disease for each plot was calculated using the formula of Townsend and Heuberger (1943) as, 


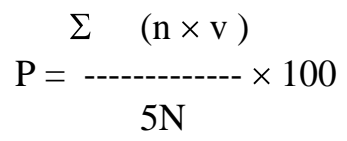

$\mathrm{P}=$ disease percent, $\mathrm{n}=$ number of plants in each index, $\mathrm{v}=$ numerical value of each index,

$\mathrm{N}=$ total number of plants.

Area under the disease progress curve (AUDPC) was calculated according to Shaner and Finney (1977),

$$
\begin{aligned}
& \mathrm{n} \\
& \text { AUDPC }=\underset{i=1}{\sum}\left[\left(\mathrm{Y}_{\mathrm{i}+1}+\mathrm{Y}_{\mathrm{i}}\right) / 2\right]\left[\mathrm{X}_{\mathrm{i}+1}-\mathrm{X}_{\mathrm{i}}\right]
\end{aligned}
$$

In which, $Y_{i}=$ disease index (per unit) at ith observation, $X_{i}=$ time (day) and $n=$ total number of observations.

One day before harvest, approximately 300-400 siliquae were collected from each plot from different heights (lower, middle and top) of racemes of 10 tagged plants. These siliquae were used for measuring 100-siliquae weight and for counting average number of seeds per siliquae. In the second year, the number of siliquae and the height of the tagged plants were also recorded. Harvest was done from net area of $3 \times$ $2.75 \mathrm{~m}$ of each plot. Total yield and 1000-seed weight were measured. The relationship between seed yield and disease severity was calculated using a linear regression model. Yield loss in percent was calculated according to Walker (1990),

$\mathrm{W}=\frac{(\mathrm{m}-\mathrm{y})}{\mathrm{m}}$

Where, $\mathrm{W}=$ yield loss $(\%), \mathrm{m}=$ yield in sprayed plot, $\mathrm{y}=$ yield in unsprayed plot.

Four hundred seeds of each plot were examined for infection of A. brassicae by the blotter method. Seed samples of $16 \mathrm{~g}$ per plot were used for measuring oil content by the Near-Infrared Reflectance Spectroscopy (NIR), InfraAlyzer 2000, Bran + Luebbe GmbH, Norderstadt Germany (Rahman et al 2001).

Daily air temperature and relative humidity were recorded with a thermohygrograph installed 2 meters above ground level and about 20 meters away from the experimental field. The recording sheet was replaced every week. Rainfall data was also collected from the nearest meteorological station. Data were analyzed statistically using ANOVA for factorial experiment in the MSTAT-C (Freed et al 1988).

\section{RESULTS}

\section{Disease and weather factors}

At Khumaltar, during December-February, maximum temperatures were $15-20^{\circ} \mathrm{C}$, minimum temperatures $1-5^{\circ} \mathrm{C}$, relative humidity $>80 \%$ and total rainfall was $49.8 \mathrm{~mm}$ in 1992 and $27.4 \mathrm{~mm}$ in 1993 (Table 1). In both years, Alternaria leaf blight incidence was very low. Only a few spots were observed in the lower leaves in the third week of January, which increased slightly in February. For both seasons, the disease severity did not exceed 5\%. No symptom was observed in the siliqua, and the difference in yield of sprayed and unsprayed plots were quite less. Therefore, only the data from Nawalpur were discussed. 


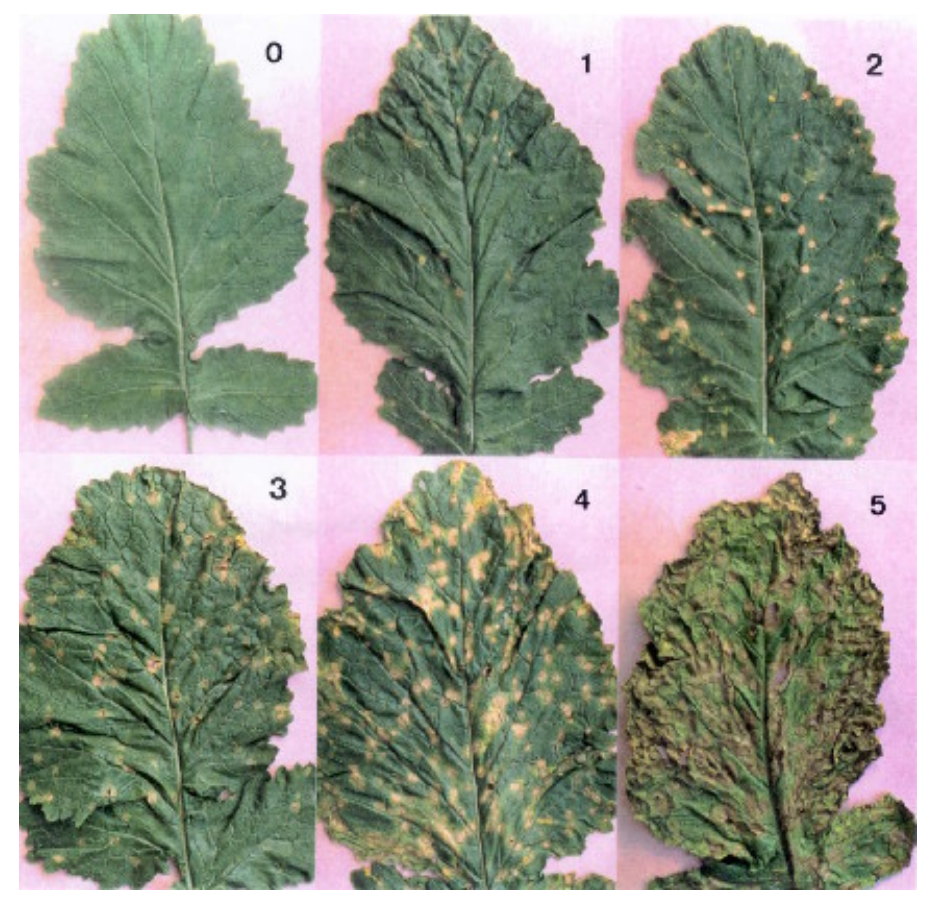

Figure 1A. Alternaria leaf blight disease index on leaves of mustard cv Krishna, $0=$ no symptom, $1=1-5 \%$ area covered by disease, $2=6-10 \%$ area covered, $3=11-20 \%$ area covered, $4-21-30 \%$ area covered, 5 $=31-100 \%$ area covered.

Figure 1B. Alternaria leaf blight disease index on pods of mustard cv Krishna, $0=$ no disease spots, $1=1-5 \%$ area covered by spots, $2=6-10 \%$ area covered, $3=11-20 \%$ area covered, $4=21-30 \%$ area covered, $5=$ $31-100 \%$ area covered. 
Table 1. A comparison of meteorological data between Khumaltar-Lalitpur and Nawalpur-Sarlahi, 1992-93

\begin{tabular}{llrrrr}
\hline Location & Time period & \multicolumn{2}{c}{ Temperature range, ${ }^{\circ} \mathrm{C}$} & Relative Humidity range, $\%$ & Rainfall, $\mathrm{mm}$ \\
\cline { 3 - 4 } & & Maximum & Minimum & & \\
\hline \multirow{2}{*}{ Khumaltar } & Oct - Nov & $20.6-24.1$ & $4.1-12.5$ & $74.5-82.6$ & 0 \\
& Dec - Feb & $15.5-19.8$ & $1.4-4.8$ & $78.2-94.3$ & $27.4-49.8$ \\
Nawalpur & Oct - Nov & $31.1-33.6$ & $16.1-25.4$ & $65.3-72.1$ & 0 \\
& Dec - Feb & $18.4-26.6$ & $10.3-14.5$ & $60.5-95.6$ & $8.6-46.7$ \\
\hline
\end{tabular}

At Nawalpur, symptoms of Alternaria leaf blight were first observed on cotyledonary leaves of a few border plants of yellow sarson (cv Psy-6) during the second week of November. However, the disease did not progress further until early December. After emergence of seedlings, the weather was slightly warm and dry with mean daily temperatures between 20 and $30^{\circ} \mathrm{C}$ and average relative humidity was less than $70 \%$ during October-November.

In the experimental plots, the disease appeared as necrotic spots on the lower leaves of the stage GS3 (Harper and Berkenkamp 1975) in the second week of December. The disease increased rapidly as daily temperature gradually decreased and relative humidity increased steadily during December-February. In this period, daily maximum temperature ranged from 18 to $27^{\circ} \mathrm{C}$, minimum temperature $10-14^{\mathrm{O}} \mathrm{C}$ and relative humidity 60-96\%. Total rainfall during those three months in 1992 was $46.7 \mathrm{~mm}$ (Table 1) and 8.6 $\mathrm{mm}$ in 1993. The rainfall along with heavy dew deposition provided wetness on leaves for about $14-15 \mathrm{~h}$ a day.

In both years, the disease progress was much faster in unsprayed plots than in fungicide-sprayed plots (Figure 2). In unsprayed plots, the disease severity reached high in the lower leaves followed by defoliation within two weeks of infection. A vertical gradient of disease infection was developed in the plants. As the disease progressed, spots appeared on the leaves of middle and upper levels of plants and the defoliation continued. After five weeks, leaves of all plants were shed in the unsprayed plots. In the sprayed plots, disease progress was much slower and the leaves remained attached to the plants for a longer period until senescence. Disease severity was slightly higher in the first season than in the second season that might be due to rainfall for 3 consecutive days in the last week of December 1992. In both years, disease progress in the cv Varuna was slightly faster than in the other two cvs, Pusabold and Krishna (Figure 2) indicating that cv Varuna is more susceptible than the other two. On pods, the disease appeared by mid January in both years. The weather conditions continued to be favorable for the disease development. The disease gradient in racemes followed the one observed in the foliage. In the early stage of infection, the spots were more frequent in the lower pods, lesser in the middle and much less in the upper pods. After the second week of February, disease development was slow in the unsprayed plots, probably due to gradual decrease in the relative humidity $(60-65 \%)$ and rise in the day temperatures $\left(26-27^{\circ} \mathrm{C}\right)$. Disease symptoms on the pods in sprayed plots were lower than in unsprayed plots (Table 2).

The ANOVA showed that there was no significant interaction between cultivars and treatments indicating that the cultivars differences were not significantly affected by the treatments and the treatments effect did not differ significantly with the cultivars tested. Main effects, both of cultivars and of treatments were significant. Hence the overall main effects of the cultivars and the treatments were compared. 
Table 2. Area under disease progress curve (AUDPC), seed yield and yield loss due to Alternaria leaf blight for three mustard cultivars at National Oilseeds Research Program, Nawalpur in 1992 and 1993

\begin{tabular}{|c|c|c|c|c|c|c|c|c|}
\hline \multirow[t]{2}{*}{ Cultivar/Treatment } & \multicolumn{4}{|c|}{1992} & \multicolumn{4}{|c|}{1993} \\
\hline & $\begin{array}{l}\text { AUDPC in } \\
\text { leaf }\end{array}$ & $\begin{array}{l}\text { AUDPC in } \\
\text { pod }\end{array}$ & $\begin{array}{l}\text { Seed } \\
\text { yield, } \\
\mathrm{kg} / \mathrm{ha}\end{array}$ & $\begin{array}{l}\text { Seed } \\
\text { yield } \\
\text { Loss, \% }\end{array}$ & $\begin{array}{l}\text { AUDPC in } \\
\text { leaf }\end{array}$ & $\begin{array}{l}\text { AUDPC in } \\
\text { pod }\end{array}$ & $\begin{array}{l}\text { Seed yield, } \\
\mathrm{kg} / \mathrm{ha}\end{array}$ & $\begin{array}{l}\text { Seed } \\
\text { yield } \\
\text { Loss, \% }\end{array}$ \\
\hline \multicolumn{9}{|l|}{ Pusabold } \\
\hline Sprayed & 67.57 & 43.42 & 746.90 & & 30.30 & 16.20 & 1270.00 & \\
\hline Unsprayed & 142.89 & 74.88 & 474.30 & & 120.83 & 69.49 & 505.70 & \\
\hline Average & $105.23 \mathrm{~b}$ & $59.15 \mathrm{~b}$ & $610.60 \mathrm{a}$ & & $75.56 \mathrm{~b}$ & $42.85 \mathrm{~b}$ & $887.85 \mathrm{~b}$ & \\
\hline \multicolumn{9}{|l|}{ Varuna } \\
\hline Sprayed & 71.55 & 52.53 & 532.80 & & 36.17 & 21.78 & 1142.00 & \\
\hline Unsprayed & 148.63 & 85.15 & 392.12 & & 130.96 & 81.36 & 487.70 & \\
\hline Average & $109.99 \mathrm{a}$ & $68.84 \mathrm{a}$ & $462.46 \mathrm{~b}$ & & $83.56 \mathrm{a}$ & $51.57 \mathrm{a}$ & $814.85 \mathrm{~b}$ & \\
\hline \multicolumn{9}{|l|}{ Krishna } \\
\hline Sprayed & 65.59 & 38.45 & 749.50 & & 28.57 & 14.77 & 1394.00 & \\
\hline Unsprayed & 137.70 & 70.80 & 498.80 & & 114.49 & 62.65 & 654.90 & \\
\hline Average & $101.65 \mathrm{~b}$ & $54.63 \mathrm{~b}$ & $624.15 \mathrm{a}$ & & $71.53 \mathrm{~b}$ & $38.71 \mathrm{~b}$ & $1024.45 \mathrm{a}$ & \\
\hline Sprayed (Av over 3 cvs) & $68.64 \mathrm{~b}$ & $44.80 \mathrm{a}$ & $676.40 \mathrm{a}$ & 32 & $31.68 \mathrm{~b}$ & $17.58 \mathrm{~b}$ & $1268.50 \mathrm{a}$ & 57 \\
\hline Unsprayed (Av over 3 cvs) & $143.07 \mathrm{a}$ & $76.94 \mathrm{~b}$ & $455.07 \mathrm{~b}$ & & $122.09 \mathrm{a}$ & $71.17 \mathrm{a}$ & $549.43 \mathrm{~b}$ & \\
\hline \multicolumn{9}{|l|}{ P-value } \\
\hline A (Cultivar) & $(0 .<001)$ & $(0 .<001)$ & $(0 .<001)$ & & $(0<.001)$ & $(0 .<001)$ & $(0.002)$ & \\
\hline B (Treatment) & $(0 .<001)$ & $(0 .<001)$ & $(0 .<001)$ & & $(0 .<001)$ & $(0 .<001)$ & $(0 .<001)$ & \\
\hline $\mathrm{AB}$ (Interaction) & ns & ns & ns & & ns & ns & ns & \\
\hline $\operatorname{LSD}_{(0.05)}$ for cultivars & 3.585 & 4.99 & 65.91 & & 4.259 & 4.34 & 109.2 & \\
\hline $\operatorname{LSD}_{(0.05)}$ for treatment & 2.927 & 2.91 & 53.81 & & 3.477 & 3.12 & 89.18 & \\
\hline $\mathrm{CV}, \%$ & 4.04 & 13.34 & 13.85 & & 6.59 & 8.04 & 14.29 & \\
\hline
\end{tabular}

Means in a column with different letters are significantly different at $P=0.05$.

\section{Effect of disease severity on seed yield and yield components}

Disease measured using Area Under Disease Progress Curve (AUDPC) for both leaves and pods was significantly higher in all cultivars in the unsprayed plots than in sprayed plots (Table 2). The disease severity in the leaves and pods of cv Varuna was higher than in cvs Pusabold and Krishna. The average seed yield of all cultivars was significantly higher in sprayed than in unsprayed plots. In the first year, the yields of cvs Pusabold and Krishna were similar but that of Varuna was significantly lower. In the second year, however, cvs Pusabold and Varuna were similar but the yield of Krishna was significantly higher than that of Varuna. The average seed yield loss was 32\% in 1992 and 57\% in 1993 (Table 2). The correlation between seed yield and disease severity was negative and highly significant. Furthermore, the regression line was $\mathrm{y}=919-6.9 \mathrm{x}$ in 1992 and $\mathrm{y}=1548.5-16.9 \mathrm{x}$ in 1993. Based on a regression analysis, it was calculated that for $1 \%$ increase of Alternaria leaf blight, the yield losses ranged from 6.87 to $16.88 \mathrm{~kg} / \mathrm{ha}$ in 1992-1993. Spraying with mancozeb, the average yield increase was $48 \%$ in 1992 and by spraying iprodione, 130\% in 1993 (data not sown). 
Alternaria leaf blight affected yield components of mustard considerably (Table 3). In comparing sprayed and unsprayed treatments, the disease significantly reduced 1000-seed weight, 100-siliqua weight, number of seed per siliqua for both years and number of siliqua per plant and plant height in the second year. The simple correlation coefficients between various yield components and disease severity in leaf and siliqua were negative and significant (Table 4). Disease severity of both leaf and sliliqua was negatively correlated to 1000-seed weight and 100-siliqua weight and less to the other components indicating that the effect of Alternaria leaf blight is closely associated with these components.

Table 3. Effect of Alternaria leaf blight on yield components of three mustards cultivars grown under field conditions at National Oilseeds Research Program, Nawalpur in 1992 and 1993

\begin{tabular}{|c|c|c|c|c|c|c|c|c|}
\hline \multirow[t]{2}{*}{ Cultivar/Treatment } & \multicolumn{3}{|c|}{1992} & \multicolumn{5}{|c|}{1993} \\
\hline & $\begin{array}{l}1000- \\
\text { seed } \\
\text { weight, } \mathrm{g}\end{array}$ & $\begin{array}{l}\text { 100-siliquae } \\
\text { weight, g }\end{array}$ & $\begin{array}{l}\text { Number of } \\
\text { seeds/siliqua }\end{array}$ & $\begin{array}{l}\text { 1000-seed } \\
\text { weight, g }\end{array}$ & $\begin{array}{l}100- \\
\text { siliquae } \\
\text { weight, g }\end{array}$ & $\begin{array}{l}\text { Number of } \\
\text { seeds/siliqua }\end{array}$ & $\begin{array}{l}\text { Number of } \\
\text { siliqua/plant }\end{array}$ & $\begin{array}{l}\text { Plant } \\
\text { height, cm }\end{array}$ \\
\hline \multicolumn{9}{|l|}{ Pusabold } \\
\hline Sprayed & 4.30 & 9.86 & 11.85 & 6.57 & 12.26 & 12.62 & 112.48 & 188.66 \\
\hline Unsprayed & 3.33 & 7.76 & 10.72 & 4.57 & 9.09 & 11.72 & 77.49 & 173.66 \\
\hline Average & $3.82 \mathrm{a}$ & $8.81 \mathrm{a}$ & $11.28 \mathrm{~b}$ & $5.57 \mathrm{a}$ & $10.67 \mathrm{a}$ & $12.17 \mathrm{a}$ & $94.99 \mathrm{ab}$ & $181.16 \mathrm{a}$ \\
\hline \multicolumn{9}{|l|}{ Varuna } \\
\hline Sprayed & 2.78 & 7.69 & 11.00 & 4.37 & 8.76 & 11.58 & 98.97 & 184.83 \\
\hline Unsprayed & 2.13 & 5.84 & 10.08 & 3.37 & 6.86 & 10.57 & 71.99 & 168.33 \\
\hline Average & $2.46 \mathrm{~b}$ & $6.76 \mathrm{c}$ & $10.54 \mathrm{c}$ & $3.87 \mathrm{~b}$ & $7.81 \mathrm{c}$ & $11.08 \mathrm{~b}$ & $85.48 \mathrm{~b}$ & $176.58 \mathrm{~b}$ \\
\hline \multicolumn{9}{|l|}{ Krishna } \\
\hline Sprayed & 4.38 & 8.69 & 11.90 & 4.56 & 9.80 & 12.52 & 125.83 & 195.66 \\
\hline Unsprayed & 3.04 & 6.74 & 11.06 & 3.48 & 7.45 & 11.73 & 82.59 & 180.00 \\
\hline Average & $3.71 \mathrm{a}$ & $7.71 \mathrm{~b}$ & $11.48 \mathrm{a}$ & $4.02 \mathrm{~b}$ & $8.63 \mathrm{~b}$ & $12.13 \mathrm{a}$ & $104.21 \mathrm{a}$ & $187.83 \mathrm{a}$ \\
\hline Sprayed (Av over 3 cvs) & $3.82 \mathrm{a}$ & $8.74 \mathrm{a}$ & $11.58 \mathrm{a}$ & $5.17 \mathrm{a}$ & $10.27 \mathrm{a}$ & $12.24 \mathrm{a}$ & $112.43 \mathrm{a}$ & $189.72 \mathrm{a}$ \\
\hline Unsprayed (Av over 3 cvs) & $2.83 \mathrm{~b}$ & $6.78 \mathrm{~b}$ & $10.62 \mathrm{~b}$ & $3.81 \mathrm{~b}$ & $7.80 \mathrm{~b}$ & $11.34 \mathrm{~b}$ & $77.36 \mathrm{~b}$ & $173.99 \mathrm{~b}$ \\
\hline \multicolumn{9}{|l|}{ P-value } \\
\hline A (Cultivar) & $(0 .<001)$ & $(0 .<001)$ & $(0.05)$ & $(0 .<001)$ & $(0 .<001)$ & $(0 .<001)$ & $(0.01)$ & $(0.005)$ \\
\hline B (Treatment) & $(0 .<001)$ & $(0 .<001)$ & $(0.02)$ & $(0 .<001)$ & $(0 .<001)$ & $(0 .<001)$ & $(0 .<001)$ & $(0 .<001)$ \\
\hline $\mathrm{AB}$ (Interaction) & ns & ns & ns & ns & ns & ns & ns & ns \\
\hline $\operatorname{LSD}_{(0.05)}$ for cultivars & 0.298 & 0.837 & 0.059 & 0.275 & 0.614 & 0.559 & 17.80 & 6.747 \\
\hline $\operatorname{LSD}_{(0.05)}$ for treatment & 0.244 & 0.683 & 0.049 & 0.224 & 0.501 & 0.456 & 14.53 & 5.509 \\
\hline $\mathrm{CV}, \%$ & 10.69 & 12.81 & 7.40 & 7.28 & 8.05 & 5.64 & 22.33 & 4.42 \\
\hline
\end{tabular}

Means in a column with different letters are significantly different at $P=0.05$.

Table 4. Simple correlation coefficients for seed yield, yield components and disease severity of mustard grown at National Oil Research Program, Nawalpur, 1992 and 1993

\begin{tabular}{|c|c|c|c|c|}
\hline \multirow[t]{2}{*}{ Seed yield and yield components } & \multicolumn{2}{|c|}{1992} & \multicolumn{2}{|c|}{1993} \\
\hline & $\begin{array}{l}\text { Leaf disease } \\
\text { severity }\end{array}$ & $\begin{array}{l}\text { Siliquae disease } \\
\text { severity }\end{array}$ & $\begin{array}{l}\text { Leaf disease } \\
\text { severity }\end{array}$ & $\begin{array}{l}\text { Siliquae disease } \\
\text { severity }\end{array}$ \\
\hline Seed yield & $-0.738 * * *$ & $-0.760 * * *$ & $-0.937 * * *$ & $-0.936 * * *$ \\
\hline 1000-seed weight & $-610 * * *$ & $-0.711 * * *$ & $-0.636 * * *$ & $-0.675 * * *$ \\
\hline Number of siliqua/plant & - & - & $-0.564 * * *$ & $-0.601 * * *$ \\
\hline Number of seeds/siliqua & $-0.458 * *$ & $-0.466 * *$ & $-0.550 * * *$ & $-0.630 * * *$ \\
\hline 100-siliquae weight & $-0.655 * * *$ & $-0.690 * * *$ & $-0.686^{* * * *}$ & $-0.737 * * *$ \\
\hline
\end{tabular}

\section{Seed infection and oil content}

In the first year, average seed infection in cvs Puseabold and Varuna were similar but in cv Krishna, it was significantly lower than other two cultivars. However in the second year, the cultivars did not differ with respect to seed infection. Moreover, average seed infection of three cultivars from sprayed plots was significantly lower than in the seeds from unsprayed plots in 1992 and highly significantly in 1993. Average percent of oil content in the seeds of Pusabold was lower than other two cultivars in the first year but in the next year its level was high. However, in the seeds of Varuna and Krishna the level of oil content was remained same in both years (Table 5). Among treatments, average percent of oil content in the seeds of all cultivars from sprayed plots was significantly higher than in the seeds from unsprayed plots in both years. The average oil reduction was calculated as $4.5 \%$ in the first year and $4.2 \%$ in the second year. The coefficient of correlation between seed infection and oil content was significantly negative in 1993. Similarly, relationship between oil and protein content in the seeds of mustards of 1993 was negative (Figure 3). 


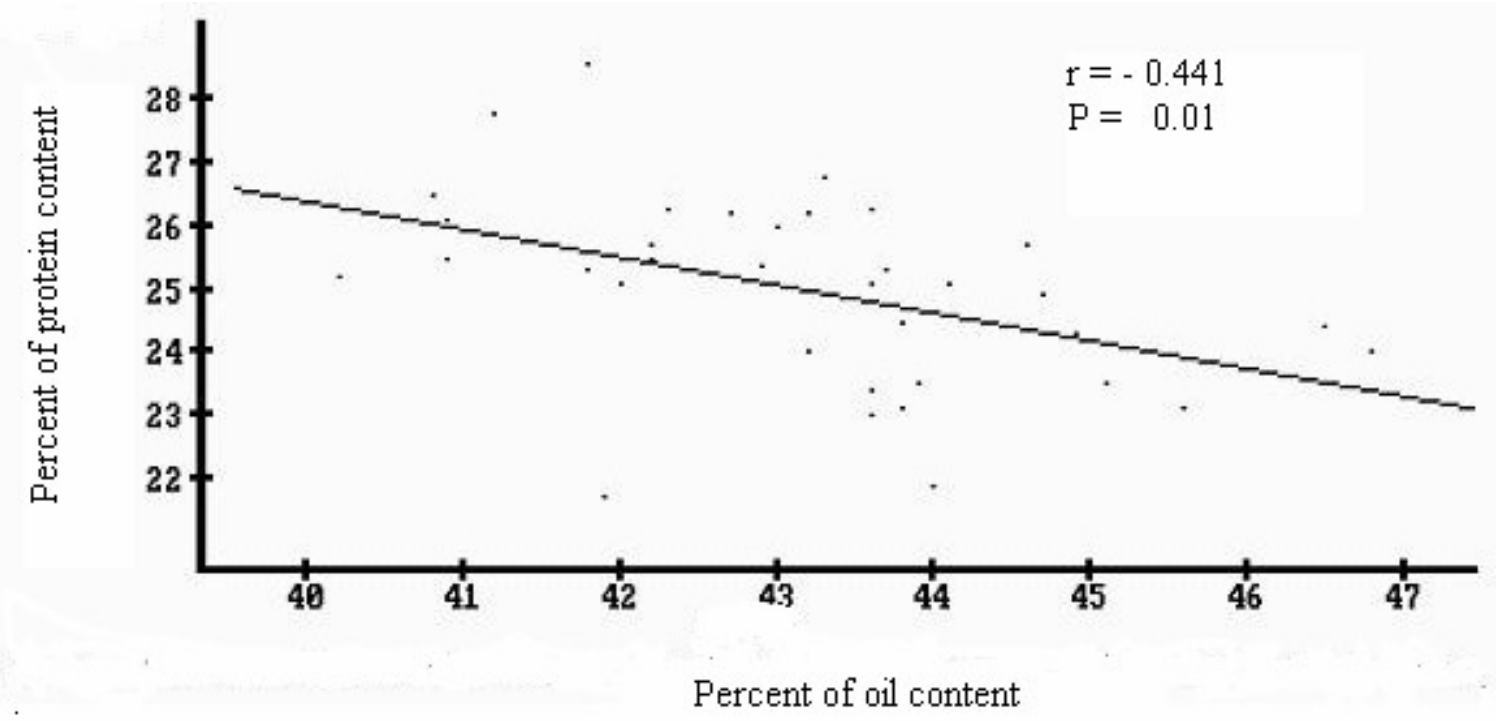

Figure 3. Relationship between oil and protein content in the seeds of mustard, 1993.

Table 5. Seed infection of Alternaria brassicae and oil content of three mustard cultivars grown at National Oilseeds Research Program, Nawalpur, 1992 and 1993

\begin{tabular}{|c|c|c|c|c|c|c|}
\hline & 1992 & & & 1993 & & \\
\hline Cultivar/Treatment & $\begin{array}{l}\text { Seed } \\
\text { infection, \% }\end{array}$ & $\begin{array}{l}\text { Oil content, } \\
\%\end{array}$ & $\begin{array}{l}\text { Average } \\
\text { oil loss, } \%\end{array}$ & $\begin{array}{l}\text { Seed } \\
\text { infection, \% }\end{array}$ & $\begin{array}{l}\text { Oil content, } \\
\%\end{array}$ & $\begin{array}{l}\text { Average oil } \\
\text { loss, \% }\end{array}$ \\
\hline \multicolumn{7}{|l|}{ Pusabold } \\
\hline Sprayed & 32.26 & 44.10 & & 5.53 & 44.42 & \\
\hline Unspray & 33.48 & 40.12 & & 19.87 & 42.30 & \\
\hline Average & $32.87 \mathrm{a}$ & $42.11 \mathrm{c}$ & & $12.70 \mathrm{a}$ & $43.36 \mathrm{a}$ & \\
\hline \multicolumn{7}{|l|}{ Varuna } \\
\hline Sprayed & 31.82 & 44.22 & & 6.29 & 44.72 & \\
\hline Unsprayed & 34.05 & 43.17 & & 22.74 & 43.12 & \\
\hline Average & $32.93 \mathrm{a}$ & $43.69 \mathrm{a}$ & & $14.51 \mathrm{a}$ & $43.92 \mathrm{a}$ & \\
\hline \multicolumn{7}{|l|}{ Krishna } \\
\hline Sprayed & 29.10 & 43.45 & & 6.23 & 43.38 & \\
\hline Unsprayed & 33.66 & 42.47 & & 19.38 & 41.53 & \\
\hline Average & $31.35 \mathrm{~b}$ & $42.96 \mathrm{~b}$ & & $12.80 \mathrm{a}$ & $42.46 \mathrm{~b}$ & \\
\hline Spraye (Av over 3 cvs) & $31.06 \mathrm{~b}$ & $43.92 \mathrm{a}$ & & $6.01 \mathrm{~b}$ & $44.17 \mathrm{a}$ & \\
\hline Unsprayed (Av over 3 cvs) & $33.73 \mathrm{a}$ & $41.92 \mathrm{~b}$ & 4.55 & $20.66 \mathrm{a}$ & $42.32 \mathrm{~b}$ & 4.20 \\
\hline \multicolumn{7}{|l|}{ P-value } \\
\hline A (Cultivar) & 0.05 & $0 .<01$ & & 0.04 & 0.01 & \\
\hline B (Treatment) & 0.05 & $0 .<01$ & & 0.01 & $0 .<01$ & \\
\hline $\mathrm{AB}$ (Interaction) & NS & NS & & NS & NS & \\
\hline $\operatorname{LSD}_{(0.05)}$ for cultivars & 1.02 & 0.37 & & 1.20 & 0.86 & \\
\hline $\operatorname{LSD}_{(0.05)}$ for treatment & 1.96 & 0.31 & & 1.48 & 0.71 & \\
\hline $\mathrm{CV}, \%$ & 10.80 & 1.04 & & 21.35 & 2.37 & \\
\hline
\end{tabular}

Means in a column with different letters are significantly different at $\mathrm{P}=0.05$.

\section{DISCUSSION}

Mustard is grown in many parts of Nepal but the major belt for production of seed for oil extraction is the Tarai (plain), which extends all along the length of the country bordering India. The crop is attacked by Alternaria brassicae causing leaf blight all over the country, but the severity of the disease is much higher in Tarai (Shrestha and Shrestha 1992). That is why the experiments were conducted at Nawalpur, Sarlahi. 
The second experiment site was Khumaltar, which represented the mid hill of the country. The experiments conducted with 3 popular cultivars clearly show that environmental conditions recorded at the two locations were very different. The environmental conditions, which were prevalent at Nawalpur during two years of experiments, favored the disease development of Alternaria leaf blight. These conditions were 80-90\% relative humidity, maximum temperature ranging from $18-25^{\circ} \mathrm{C}$, minimum from $10-14^{\circ} \mathrm{C}$ and $14-15 \mathrm{~h}$ wetness period daily with dews from $6 \mathrm{pm}$. to 9 am during the months of December and January.

Our assessments show that the critical period for disease development in the foliage was from $2^{\text {nd }}$ week of December to the 3rd week of January. During this period, the disease appeared in severe form in the both years causing heavy damage to the plants in the unsprayed plots. At first the disease was observed as small grayish-brown necrotic spots on leaves, which later coalesced each other causing leaf blight. At Nawalpur there was a rapid and steep progression of the disease on the leaves until total defoliation and the initiation of black spot disease on the pods. Favorable weather conditions continued until the $2^{\text {nd }}$ week of February and at this time the pods were severely infected. After the $2^{\text {nd }}$ week of February there was no increase in the disease severity. This may have been due to gradual decline in relative humidity and rise in temperature. Similar observations on the progression of disease in relation to climatic factors have been made in United Kingdom (Humpherson-Jones and Phelps 1989, Mridha and Wheeler 1993) and India (Duhan and Suhag, 1990). We believe that the period between mid December and the $3^{\text {rd }}$ week of January when maximum foliage infection was seen, is the most critical period for the epidemics of the Alternaria leaf blight of mustard. During this period the fungus sporulated profusely in the necrotic areas of diseased leaves. At Khumaltar, disease level was very low, usually in the form of a few leaf spots on the lower leaves. No blight symptoms were observed.

Alternaria brassicae is known to cause seed infection and the infected seeds have already been shown to act as main source of recurrence of the disease in the field (Shrestha et al 2000). Besides, A. brassicae was found to survive for 8 months in the seeds of rapeseed stored in local containers in the farmhouse at Nawalpur (Shrestha and Chaudhary 1999). At room temperatures $\left(11-25^{\circ} \mathrm{C}\right)$ the fungus survived in the seeds for more than 6 months (Shrestha et al 2003). In general, the farmers store the seeds of rapeseed and mustard for 6-7 months before sowing. Although Alternaria disease-free seeds were sown in the experimental plots in both years, the border rows were planted with infected seeds of yellow sarson. The infected plants of border rows might act as primary source of inoculum. Since the disease was more severe at Nawalpur, seeds produced by the farmers in the Tarai should not be used for sowing without seed treatment. We recommend that mid hill of the country should be chosen for seed production because seeds produced in these areas will be less infected by Alternaria brassicae. Sowing of such seeds will give healthier crops and the production of oil in the country will be increased. The negative correlation between seed yield and disease severity of leaf and pod stress the importance of keeping the crop disease-free. Shrestha and Chaudhary (2001) showed that seed infection has a direct effect on 1000-seed weight and ultimately on seed yield. One of the ways to control leaf blight in the field is spraying with effective fungicides during the critical phase of disease development. This was achieved in the present study by the use of mancozeb, which is available easily in Nepal. Five applications of this fungicide from mid December to early February controlled the disease significantly, with an increase in seed yield of $48 \%$. The cost benefit ratio was 1:2. However, more experiments are needed to establish the optimal number of fungicidal applications. The authors advise that fungicides should be applied judiciously by the farmers during the critical period of disease development, as no resistant cultivars against Alternaria leaf blight are available. Although iprodione gave better control of the disease in our experiments, with an increase in yield by $130 \%$, it is slightly expensive than mancozeb.

Oil extracted from rapeseed and mustard in Nepal is the main source of edible oil. Therefore, these crops are of great economic value. Our results clearly demonstrate that the increase in seed yield will result in the increase of oil production if the disease is controlled adequately. In Nepal, there is no separate statistical 
information on area and production of these rapeseed and mustard crops. However, MoAC (2004) states that area, production and productivity of the oilseeds are 1,88, $455 \mathrm{ha}, 1,24,930 \mathrm{mt}$ and $669 \mathrm{~kg} / \mathrm{ha}$ respectively. By controlling the disease with mancozeb alone, there can be an increase of 20,988 mt of oil on national basis. The figure can even increase up to 58,155 mt, if the leaf blight disease is controlled with iprodione. However, increasing percent of oil content in the seeds of oilseeds reduces percentage of protein and vice versa. This fact is supported by Ward et al (1985). Therefore, breeders should select genotypes jointly for oil and protein content than for either factor alone. This may help to increase oil content with minimum loss in protein.

Varuna is more susceptible than the other two cultivars. At Khumaltar, the yield of all three cultivars was not significantly different for both years. But at Nawalpur, where the disease severity was high, the yield of Krishna was significantly higher than the yield of Varuna in both years and with Pusabold, the yield was at par. It is recommended to use Alternaria free seed for sowing, choose the least susceptible cultivars and spray with effective fungicide at critical periods during the disease development. These factors will be important in an integrated Alternaria leaf blight management programme of Nepal.

\section{ACKNOWLEDGEMENTS}

The authors gratefully acknowledge the Danish International Development Agency (DANIDA) for providing research grant to first author. They also wish to thank to GP Koirala, B Mishra, National Oil Research Program, Nawalpur. They would like to thank Dr H Rahaman, Maribo Seed, Denmark for analyzing oil content and protein of the mustard seeds samples. The authors are also thankful to B Adhikary for his suggestions in analyzing field data.

\section{REFERENCES}

Ansari NA, MW Khan and A Muheet. 1988. Effect of Alternaria blight on oil content of rapeseed and mustard. Current Science 57:1023-1024.

Ansari NA, MW Khan and A Muheet. 1989. Effect of some factors on growth on sporulation of Alternaria brasicae causing Alternaria blight of rapeseed and mustard. Acta Botanica Indica 17:49-53.

ATSP, USAID/HMG-NARC. 1993. A report of rapid rural appraisal (RRA) at Rampur ARS command area on survey for the winter season focused on rapeseed/mustard, Nepal.

Conn KL, JP Tiwari and RP Awasthi. 1990. A disease assessment key for Alternaria blackspot in rapeseed and mustard. Canadian Plant Disease Survey 70:19-22.

Degenhardt KJ, GA Petrie and RAA Morrall. 1982. Effects of temperature on spore germination and infection of rapeseed by Alternaria brassicae, A. brassicicola and A. raphani. Canadian Journal of Plant Pathology 4:115118.

Degenhardt KJ, WP Skoropad and ZP Kondra. 1974. Effects of Alternaria blackspot on yield, oil content and protein content of rapeseed. Canadian Journal of Plant Science 54:795-799.

Duhan JC and KS Suhag. 1990. Alternaria leaf and pod blight of cauliflower. Indian Phytopathology 43:231-234.

Freed R, SP Eisensmith, S Goetz, D Reicosky, VW Smail and P Wolberg. 1988. MSTAT-C, a software program for the design, management and analysis of agronomic research experiments. Michigan State University, Department of Crop and Soil Sciences and Department of Agricultural Economics, USA.

Harper FR and B Berkenkamp. 1975. Revised growth-stage key for Brassica campestris and B. napus. Canadian Journal of Plant Science 55:657-658.

Hong CX and Fitt BD. 1995. Effect of inoculum concentration, leaf age and wetness period on the development of dark leaf and pod spot (Alternaria brassicae) on oil seed rape (Brassicae napus). Annals Applied Biology 127(2):283-295.

Humpherson-Jones FM and K Phelps. 1989. Climatic factors influencing spore production in Alternaria brassicae and Alternaria brassicicola. Annals Applied Biology 114:449-458. 
Kadian AK and GS Saharan. 1983. Symtomatology, host range and assessment of yield losses due to Alternaria brassicae infection in rapeseed and mustard. Indian Journal of Mycology and Plant Pathology 13:319-323.

Kolte SJ, RP Awasthi, and Vishwanath. 1987. Assessment of yield losses due to Alternaria blight in rapeseed and mustard. Indian Phytopathology 40:209-211.

Kumar PR. 1986. Rapeseed-mustard research in India. In: Proceedings of the SAARC Member Countries Counterpart Scientists Meeting for Multi-location Trial on Rapeseed-Mustard, 9-11 Dec, Kathmandu-Nepal.

Limonard T. 1966. A modified blotter test for seed health. Netherlands Journal of Plant Pathology 72:319-321.

McDonald MC. 1959. Gray leaf spot of rape in Manitoba. Canadian Journal of Plant Science 39:409-418.

MoAC. 2004. Statistical information on Nepalese agriculture 2002/2003. Agri-Business Promotion and Statistics Division-Ministry of Agriculture and Cooperatives, HMG, Nepal. 110pp.

Mridha MAU and BEJ Wheeler. 1993. In vitro effects of temperature and wet periods on infection of oilseed rape by A. brassicae. Plant Pathology 42:671-675.

NARC. 1988. Annual report (1977-1988). Nepal Agricultural Research Council, Khumaltar, Lalitpur, Nepal.

Rahman MH, M Joersbo and MH Poulsen 2001. Development of yellow-seeded Brassica napus of double low quality. Plant Breeding 120:473-478.

Ram RS and Chauhan VB. 1998. Assessment of yield loss due to Alternaria leaf spot in various cultivars of mustard and rapeseed. Journal of Mycopathological Research 36:(2)109-111.

Seidle E, S Rude and A Petrie. 1995. The effect of Alternaria black spot of canola on seed quality and seed yield and studies on disease control. Agriculture and Agri-Food Canada Saskatoon, Canada 41pp.

Shaner G and RE Finney. 1977. The effect of nitrogen fertilization on the expression of slow-mildewing resistance to knox wheat. Phytopathology 67:1051-1056.

Shrestha K and SK Shrestha. 1992. Major diseases of rapeseed-mustard and their control measures. In: Proc. of the First HMG/DANIDA/FAO National Training Course of Seed Production of Rapeseed-Mustard Crops. Nawalpur, Sarlahi. Pp.131-160.

Shrestha SK and RN Chaudhary. 1999. Survival of Alternaria brassicae in seeds of rapeseed-mustard stored in different containers in the farmers' storage conditions. In: Proc. of III National Conference on Science and Technology, Kathmandu-Nepal. Pp. 1076-1081.

Shrestha SK and RN Chaudhary. 2001. Effect of fungicides on Alternaria leaf blight of rapeseed crop and the measurement of correlation coefficient between infection of disease in the field and corresponding seed infection in laboratory test. In: Proc. of Society of Agriculture Scientists (SAS) Convention (HK Manandhar, CL Shrestha, RK Shrestha and SM Pradhan, eds), 10-12 June, Nepal. Pp. 135-138.

Shrestha SK, L Munk and SB Mathur. 2003. Survival of Alternaria brassicae in seeds and crop debris of rapeseed and mustard in Nepal. Seed Science and Technology Journal 31:103-109.

Shrestha SK, SB Mathur and L Munk. 2000. Transmission of Alternaria brassicae in seeds of rapeseed and mustard, its location in seeds and control. Seed Science and Technology Journal 28:75-84.

Singh A. and TP Bhowmik. 1985. Persistence and efficacy of some common fungicide against Alternaria brassicae, the causal agent of leaf blight of rapeseed and mustard. Indian Phytopathology 38: 35-38.

Townsend GR and JW Heuberger. 1943. Methods for estimating losses caused by diseases in fungicide experiments. Plant Disease Reporter 27:340-343.

Walker PT. 1990. Insect pest-loss relationship: Characteristics and importance. In: Crop Loss Assessment in Rice. International Rice Research Institute, Philippines. Pp. 71-184.

Ward JT, WD Basford, JH Hawkins and JM Holliday.1985. Oilseed rape. Farming Press, Ltd. Wharfedale Road, Ipswick, Suffolk, Great Britain. 